\title{
PERANCANGAN DAN IMPLEMENTASI JARINGAN SARAF TIRUAN BACKPROPAGATION UNTUK MENDIAGNOSA PENYAKIT KULIT
}

\author{
Nurul Mutiani Sukarno ${ }^{1}$, Panji Wisnu Wirawan ${ }^{2}$, dan Satriyo Adhy ${ }^{3}$ \\ Jurusan Ilmu Komputer / Informatika Matematika Universitas Diponegoro \\ Email :nurul.mutiani@gmail.com ${ }^{1}, \underline{\text { maspanji@undip.ac.id }}^{2}, \underline{\text { satriyo@, undip.ac.id }}^{3}$
}

\begin{abstract}
Skin has a great risk to be suffering from disease. Skin disease is easy to see by the other people, which could urge patient to look for health services and medications immediately. However, most people are less conscious about their skin diseases because many new skin disease which not familiar for patient, so that the skin disease can't be handle and become worse. Information technology could solve those problems by capturing data and deliver optimal output using particular processes. This research aims to overcome the problem by developing a web based information system that implements backpropagation neural network. The symptoms of skin diseases are used as inputs and the match skin disease as output. The architecture of backpropagation neural network in this researchhas four input neurons on input layer, a hidden layer with adjustable amount of neurons and an output neuron on output layer. As a result the most optimal recognition value with validity percentage of $100 \%$ on data training and $40 \%$ on data testing with training time in 6 hours and 10 minutes using 100000 maximum epoch, 0.0001 minimum error, 0.4 learning rate and 20 neurons in hidden layer.
\end{abstract}

Keywords : skin disease, neural network, backpropagation, web based

\section{PENDAHULUAN}

Kulit merupakan organ terbesar pada tubuh manusia yang membungkus otot-otot dan organ dalam.Kulit memiliki risiko yang sangat tinggi untuk terserang penyakit karena merupakan jalinan jaringan pembuluh darah, saraf dan kelenjar yang tidak berujung.Kelainan atau penyakit pada kulit mudah dilihat sehingga menyebabkan pasien mencari pelayanan kesehatan untuk segera menyembuhkannya [6].

Fakta di kehidupan sehari-hari terjadi adanya ketidakseimbangan antara jumlah pasien dan dokter. Sebagian masyarakat juga kurang mengerti mengenai penyakit kulit dan cara mengobatinya. Hal ini disebabkan oleh adanya penyakit kulit baru atau penyakit yang baru dialami oleh pasien sehingga dengan pengetahuan yang kurang, penyakit tersebut tidak ditangani dengan baik dan menjadi lebih parah.

Kemajuan ilmu kedokteran terutama dalam bidang diagnosa dan pengobatan pada tahuntahun belakangan ini menyebabkan ditemukannya penyakit kulit baru dan pengobatan baru yang tentunya mata manusia bahkan dokter spesialis kulit terkadang belum tentu dapat mengenali penyakit kulit tersebut dengan baik [6].Kemajuan teknologi informasi seperti saat ini dapat mengatasi masalah-masalah tersebut. Teknologi informasi memungkinkan untuk menyimpan data baru dan menghasilkan suatu keluaran optimal melalui proses tertentu.

Salah satu algoritma yang dapat digunakan pada suatu sistem untuk mendiagnosa suatu penyakit adalah jaringan saraf tiruan. Jaringan saraf tiruan merupakan sistem pemrosesan yang dirancang dan dilatih sedemikian rupa agar memiliki kemampuan seperti manusia dalam menyelesaikan suatu masalah yang rumit dengan melakukan proses pembelajaran melalui perubahan bobot sinapsisnya. Jaringan saraf mensimulasikan struktur proses-proses otak dan kemudian membawanya kepada perangkat lunak kelas baru yang dapat mengenali pola-pola yang kompleks serta belajar dari pengalamanpengalaman masa lalu [16].

Penelitian ini akan menerapkan jaringan saraf tiruan backpropagation untuk mendiagnosa penyakit kulit dengan cara menyimpan informasi-informasi diagnosa, cara penyembuhan penyakit kulit dan lainnya pada suatu memori. Gejala-gejala yang ditimbulkan 
pada suatu penyakit kulit akan dikodekan dalam bentuk angka dan ditransformasikan ke dalam interval [0.1, 0.9] karena menggunakan fungsi aktivasi sigmoid biner dan dimasukkan ke dalam layer masukan kemudian dilakukan pelatihan untuk mencari bobot-bobot akhir yang sesuai dengan target jenis penyakit yang telah ditentukan. Setelah pelatihan, bobot-bobot akhir akan digunakan kembali untuk mengenali jenis penyakit kulit tertentu berdasarkan gejala-gejala yang ada.

\section{TINJAUAN PUSTAKA}

Jaringan saraf tiruan adalah paradigma pemrosesan suatu informasi yang terinspirasi oleh sistem sel saraf biologi sama seperti otak yang memproses suatu informasi [15]. Jaringan saraf tiruan sama seperti halnya manusia yang belajar dari suatu contoh untuk memecahkan suatu masalah yang memiliki pola yang sama dengan contoh yang diberikan. Jaringan saraf tiruan merupakan metode pembelajaran yang bisa digunakan untuk menyelesaikan permasalahan yang bernilai diskrit, real maupun vektor [14].

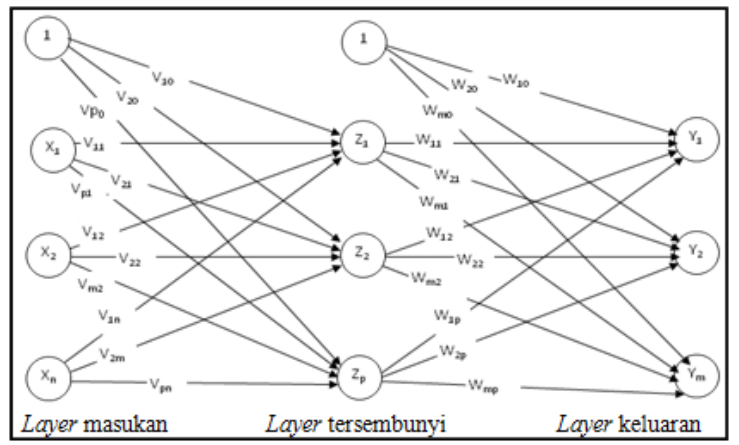

\section{Gambar 1 Arsitektur Jaringan Saraf Tiruan} Backporpagation

Jaringan saraf tiruan backpropagation merupakan salah satu model dari jaringan saraf tiruan umpan maju dengan menggunakan pembelajaran terawasi yang disusun berdasarkan pada algoritma errorbackpropagation yang didasarkan pada aturan pembelajaran koreksi kesalahan (error correction learning rule).Arsitektur jaringan saraf tiruan backpropagation terdiri dari unit masukan, unit layer tersembunyi dan unit keluaran.Arsitektur jaringan saraf tiruan backpropagation ditunjukkan pada gambar 1 .

Algoritma jaringan saraf tiruan backpropagation dapat dibagi ke dalam dua bagian, yaitu [10]:

1) Algoritma pelatihan, terdiri dari tiga tahap yaitu tahap umpan maju pola pelatihan input, tahap mempropagasibalikkan error dan tahap pengaturan bobot.

2) Algoritma aplikasi atau pengujian yang digunakan hanyalah umpan maju saja.

Algoritma backpropagationmenggunakan fungsi aktivasi seperti sigmoid biner yang ditunjukkan pada gambar 2 Karakteristik yang harus dimiliki fungsi aktivasi adalah kontinu, diferensiabel dan tidak menurun secara monoton.Fungsi sigmoid biner mempunyai range 0 hingga 1 dengan persamaan (2.1) dan dengan turunannya yang ditunjukkan pada persamaan (2.2) [10].

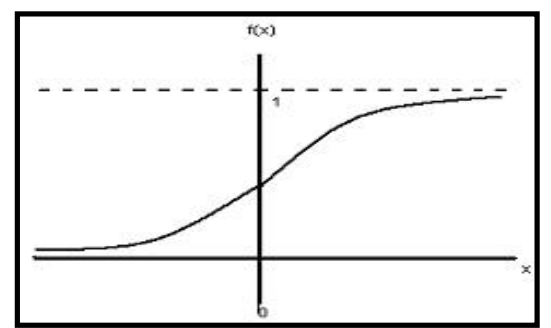

Gambar 2Grafik Sigmoid Biner [10]

$f_{1}(x)=\frac{1}{1+e^{-x}} \ldots \ldots \ldots \ldots$
$\mathrm{f}_{1}^{\prime}(\mathrm{x})=\mathrm{f}_{1}(\mathrm{x})\left(1-\mathrm{f}_{1}(\mathrm{x})\right)$

Normalisasi digunakan untuk mengecilkan range data. Normalisasi data dapat dilakukan dengan berbagai cara, diantaranya dengan cara mentransformasikan ke dalam interval tertentu. Jika fungsi aktivasi yang akan digunakan berupa fungsi aktivasi sigmoid biner, data harus ditransformasi atau dinormalisasi ke interval [0, 1] tapi akan lebih baik jika ditransformasikan ke interval yang lebih kecil, yaitu interval [0.1, 0.9]. Hal ini dikarenakan fungsi sigmoid biner merupakan fungsi asimtotik yang nilainya tidak pernah mencapai 0 ataupun 1 . 
Normalisasi data ke interval $[0.1,0.9]$ dapat dihitung dengan menggunakan persamaan (2.3).

$x^{\prime}=\frac{0,8(x-a)}{b-a}+0,1$

Pada persamaan 2.3 a merupakan data minimum dan $\mathrm{b}$ adalah data maksimum.

Setelah melakukan pelatihan dengan menggunakan algoritma jaringan saraf tiruan backpropagation maka dapat dilakukan identifikasi secara langsung dengan memberikan input dan jaringan akan mengklasifikasikan sesuai dengan bobot-bobot yang diperoleh dari proses pelatihan. Perhitungan MSE digunakan untuk mengukur apakah jaringan saraf tiruan dapat melakukan proses belajar dengan baik. MSE ini merupakan pengukuran ketepatan jaringan saraf tiruan terhadap data target pembelajaran. MSE pada keluaran jaringan saraf tiruan merupakan selisih antara keluaran yang didapat dari proses pembelajaran dengan target yang diinginkan dari masukan data tertentu. Data pembelajaran merupakan data yang dijadikan sebagai pembanding pada proses pembelajaran, sedangkan pada proses pengujian, data yang dipakai adalah data uji [2].

Cara menghitung MSE untuk kumpulan data d pada jaringan saraf tiruan dengan kumpulan neuron keluaran ditunjukkan pada persamaan 2.4 [2].

$M S E=\frac{\sum_{d} \sum_{k \in \text { output }}\left(t_{k}-o_{k}\right)^{2}}{n_{d} n_{\text {outputs }}}$

Keterangan :

$t_{k} \quad$ : nilai target pada neuron keluaran ke-k

$\mathrm{o}_{\mathrm{k}} \quad$ : nilai output pada neuron keluaran ke-k

$\mathrm{n}_{\mathrm{d}} \quad$ : jumlah data pembelajaran dan

$\mathrm{n}_{\text {output }}$ : jumlah neuron keluaran

Kinerja dari suatu jaringan saraf tiruan setelah dilakukan pelatihan dapat diukur dengan melihat error hasil pelatihan dan pengujian.Hasil pelatihan dan pengujian dapat dianalisis dengan mengamati ketepatan akurasi antara target dengan keluaran jaringan ditunjukkan pada persamaan (2.5) [4].

Persentase Kebenaran $=$

$\left|\frac{\text { jml.datauji-jml.kesalahanluaranJST }}{\text { jml.datauji }} \times 100 \%\right| \ldots \ldots .$.
Pengertian Kulit dan Beberapa Penyakit Kulit

Kulit adalah organ tubuh yang terletak paling luar dan membatasinya dari lingkungan hidup manusia.Kulit juga sangat kompleks, elastis dan sensitif, bervariasi pada keadaan iklim, umur, seks, ras dan juga bergantung pada lokasi tubuh. [12].

Pembagian lapisan kulit secara garis besar tersusun atas tiga lapisan utama terdiri dari [12]:

1) Lapisan epidermis atau kutikel

2) Lapisan dermis (korium, kutis vera, true skin)

3) Lapisan subkutis (hipodermis)

Kulit dapat dengan mudah dilihat dan diraba, hidup dan menjamin kelangsungan hidup.Kulitpun menyokong penampilan dan kepribadian seseorang.Dengan demikian kulit pada manusia mempunyai peranan yang sangat penting. Fungsi utama kulit adalah sebagai berikut [12]:

1) Fungsi proteksi, kulit menjaga bagian dalam tubuh terhadap gangguan fisis atau mekanis.

2) Fungsi absorpsi, kulit yang sehat tidak mudah menyerap air, larutan dan benda padat, tetapi cairan yang mudah menguap mudah diserap, begitupun yang larut lemak.

3) Fungsi ekskresi, kelenjar-kelenjar kulit mengeluarkan zat-zat yang tidak berguna lagi atau sisa metabolisme dalam tubuh berupa $\mathrm{NaCl}$, urea, asam urat dan amonia.

4) Fungsi persepsi, kulit mengandung ujungujung saraf sensorik di dermis dan subkutis.

5) Fungsi pengaturan suhu tubuh, kulit melakukan peranan ini dengan cara mengeluarkan keringat dan mengerutkan (otot kontraksi) pembuluh darah kulit.

6) Fungsi pembentukan pigmen, sel pembentuk pigmen terletak di lapisan basal.

7) Fungsi keratinisasi, proses ini berlangsung untuk memberi perlindungan kulit terhadap infeksi secara mekanis fisiologik.

8) Fungsi pembentukan vitamin D, dimungkinkan dengan mengubah 7 dihidroksi kolesterol dengan pertolongan sinar matahari.

Penyakit kulit yang terjadi pada manusia antara lain adalah sebagai berikut [8]: 
1) Penyakit kulit yang disebabkan oleh jamur, antara lain : panu, tinea kapitis, tinea manus dan sebagainya.

2) Penyakit kulit yang disebabkan oleh bakteri, antara lain : lepra, kusta, patek dan sebagainya.

3) Penyakit kulit yang disebabkan oleh virus, antara lain : herpes, varisela, kondiloma dan sebagainya.

4) Penyakit kulit yang disebabkan karena alergi.

\section{ANALISIS DAN PERANCANGAN}

Gambaran umum sistem yang akan dikembangkan dapat dilihat pada gambar 3 .

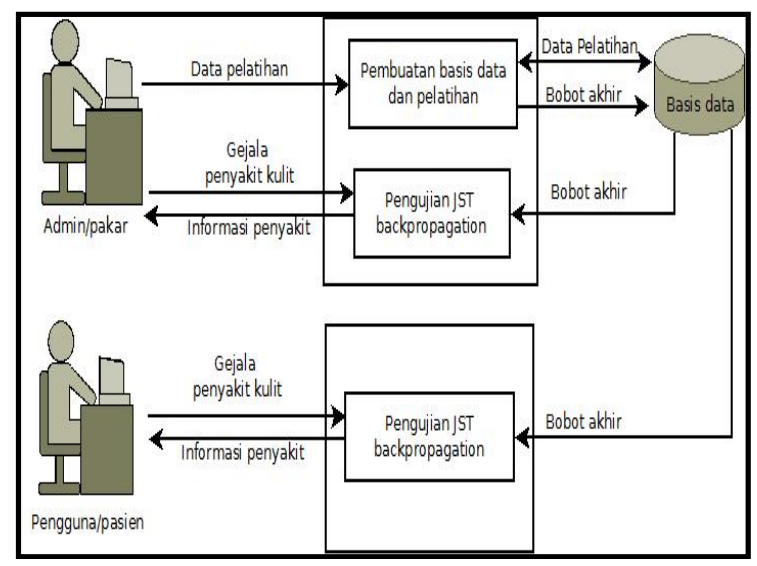

Gambar 3 Gambaran Umum Sistem Informasi Jaringan Saraf Tiruan Backpropagation untuk Mendiagnosa Penyakit Kulit

Sistem informasi ini dapat digunakan oleh dua tipe pengguna yaitu admin dan pasien.Secara garis besar, admin adalah pengguna yang dapat membuat basis data, pelatihan dan pengujian terhadap pelatihan yang telah dilakukan sebelumnya. Proses pembuatan basis data dan pelatihan hanya dapat dilakukan oleh admin dengan memasukkan data pelatihan yang terdiri dari gejala, data penyakit, relasi antara gejala dan penyakitnya, laju pemahaman, besarnya error, jumlah epoch, serta jumlah layer tersembunyi pada sistem informasi dan akan menyimpan data-data tersebut ke dalam basis data. Data yang telah disimpan ke dalam basis data akan diproses dengan menggunakan algoritma pelatihan jaringan saraf tiruan backpropagation sehingga akan menghasilkan keluaran berupa bobot akhir yang akan disimpan pada basis data. Admin juga dapat memasukkan gejala penyakit kulit dan akan diproses dengan memasukkan data bobot akhir dari basis data sehingga menghasilkan keluaran berupa informasi penyakit kulit berdasarkan gejalagejala yang sesuai pada proses pengujian jaringan saraf tiruan backpropagation.

Admin adalah seseorang yang mengerti tentang jaringan saraf tiruan backpropagation karena pada saat proses pembuatan basis data dan pelatihan, admin harus dapat melakukan pelatihan jaringan saraf tiruan backpropagation dengan memasukkan data pelatihan yang benar. Sedangkan pasien adalah pengguna yang hanya dapat melakukan pengujian terhadap pelatihan yang telah dilakukan oleh admin yaitu melakukan diagnosa dengan memasukkan data gejala penyakit kulit untuk diproses dengan memasukkan data bobot akhir dari basis data sehingga akan dihasilkan keluaran berupa informasi penyakit kulit.

\section{Analisis Data}

Pembuatan sistem informasi jaringan saraf tiruan backpropagation untuk mendiagnosa penyakit kulit ini menggunakan sekumpulan data penyakit kulit dengan empat kategori gejala yang terdiri dari lokasi, rasa, warna dan tekstur penyakit kulit beserta pengobatannya yang diperoleh dari seorang dokter spesialis kulit dan kelamin yang membuka praktek di Klinik UCM Jl. HOS Cokroaminoto No. 84 Ungaran yaitu dr. Puguh Riyanto, SpKK. Data yang diberikan dibagi menjadi dua data yaitu data pelatihan dan data pengujian. Data-data tersebut dikonversi dalam bentuk angka pada setiap kategorinya yang dapat dilihat pada tabel 1 untuk hasil konversi gejala berupa lokasi penyakit kulit, tabel 2 berupa hasil konversi hal yang dirasakan oleh pasien pada penyakit kulit tersebut, tabel 3 untuk hasil konversi gejala berupa warna penyakit, tabel 4 untuk hasil konversi gejala berupa tekstur dari penyakit kulit dan tabel 5 untuk hasil konversi dari penyakit kulit.

Berdasarkan data tersebut maka dibuat kombinasi dari seluruh data sehingga menghasilkan 40 data yang akan dibagi menjadi 30 data pelatihan dan 10 data pengujian. 
Tabel 1. Hasil Konversi Gejala Berupa Lokasi Penyakit Kulit

\begin{tabular}{|c|c|c|}
\hline No & Lokasi & $\begin{array}{c}\text { Hasil } \\
\text { Konversi }\end{array}$ \\
\hline 1. & Kepala & 1 \\
\hline 2. & Leher & 2 \\
\hline 3. & Badan dan Punggung & 3 \\
\hline 4. & Tangan & 4 \\
\hline 5. & Kaki & 5 \\
\hline
\end{tabular}

Tabel 2 Hasil Konversi Gejala Berupa Hal yang Dirasakan pada Kulit yang Terkena Penyakit

\begin{tabular}{|c|c|c|}
\hline No & Rasa & $\begin{array}{c}\text { Hasil } \\
\text { Konversi }\end{array}$ \\
\hline 1. & Gatal & 1 \\
\hline 2. & Tidak Gatal & 2 \\
\hline
\end{tabular}

Tabel 3. Hasil Konversi Gejala Berupa Warna Penyakit

\begin{tabular}{|c|c|c|}
\hline No & Warna & $\begin{array}{c}\text { Hasil } \\
\text { Konversi }\end{array}$ \\
\hline 1. & Hitam & 1 \\
\hline 2. & Putih & 2 \\
\hline
\end{tabular}

Tabel 4. Hasil Konversi Gejala Berupa Tekstur Penyakit Kulit

\begin{tabular}{|c|c|c|}
\hline No & Tekstur & $\begin{array}{c}\text { Hasil } \\
\text { Konversi }\end{array}$ \\
\hline 1. & Bersisik & 1 \\
\hline 2. & Tidak Bersisik & 2 \\
\hline
\end{tabular}

Tabel 5. Hasil Konversi Penyakit Kulit

\begin{tabular}{|c|c|c|}
\hline No & Nama Penyakit & $\begin{array}{c}\text { Hasil } \\
\text { Konver } \\
\text { si }\end{array}$ \\
\hline 1. & $\begin{array}{c}\text { Jamur Kepala } \\
\text { (Tinea Capitis) }\end{array}$ & 1 \\
\hline 2. & Tanda Lahir (Nevus) & 2 \\
\hline 3. & $\begin{array}{c}\text { Ketombe } \\
\text { (Dermatitis Seboroik) }\end{array}$ & 3 \\
\hline 4. & $\begin{array}{c}\text { Panu } \\
\text { (Pityriasis Versicolor) }\end{array}$ & 4 \\
\hline 5. & $\begin{array}{c}\text { Tumor Wajah } \\
\text { (Karsinoma Sel Skuamosa) }\end{array}$ & 5 \\
\hline 6. & $\begin{array}{c}\text { Tahi Lalat } \\
\text { (Nevus Pigmentosus) }\end{array}$ & 6 \\
\hline 7. & Porong (Pityriasis Alba) & 7 \\
\hline 8. & Belang (Vitiligo) & 8 \\
\hline 9. & Eksim (Neuro Dermatitis) & 9 \\
\hline 10 & Bintil-bintil pada Kulit & 10 \\
\hline
\end{tabular}

\begin{tabular}{|c|c|c|}
\hline No & Nama Penyakit & $\begin{array}{c}\text { Hasil } \\
\text { Konver } \\
\text { si }\end{array}$ \\
\hline & (Skin Tag) & \\
\hline 11 & Penyakit Bersisik (Psoriasis) & 11 \\
\hline 12 & $\begin{array}{c}\text { Warna Hitam Setelah } \\
\text { Radang Kulit } \\
\text { (Hiperpigmentasi Pasca- } \\
\text { Inflamasi) }\end{array}$ & 12 \\
\hline 13 & Penuaan (Keratosis Seboroik) & 13 \\
\hline 14 & Kusta (Morbus Hansen) & 14 \\
\hline 15 & $\begin{array}{l}\text { Warna Putih Setelah Radang } \\
\text { Kulit } \\
\text { (Hipopigmentasi Pasca- } \\
\text { Inflamasi) }\end{array}$ & 15 \\
\hline 16 & Kadas (Tinea Corporis) & 16 \\
\hline 17 & Kadas Kaki (Tinea Pedis) & 17 \\
\hline
\end{tabular}

Spesifikasi Kebutuhan Perangkat Lunak

Spesifikasi kebutuhan perangkat lunak untuk mendiagnosa penyakit kulit dengan menggunakan algoritma jaringan saraf tiruan backpropagation ini dijelaskan pada tabel 6 .

Tabel 6 Spesifikasi Kebutuhan Perangkat Lunak

\begin{tabular}{|c|l|}
\hline SRS ID & \multicolumn{1}{|c|}{ Deskripsi Fungsional } \\
001 & $\begin{array}{l}\text { Pasien dapat melakukan } \\
\text { diagnosa. }\end{array}$ \\
\hline $\begin{array}{c}\text { SRS-F- } \\
002\end{array}$ & $\begin{array}{l}\text { Pasien dapat melihat informasi } \\
\text { mengenai dokter dan pembuat } \\
\text { perangkat lunak. }\end{array}$ \\
\hline $\begin{array}{c}\text { SRS-F- } \\
003\end{array}$ & $\begin{array}{l}\text { Admin dapat melakukan } \\
\text { autentikasi dengan } \\
\text { memasukkan username dan } \\
\text { password. }\end{array}$ \\
\hline $\begin{array}{c}\text { SRS-F- } \\
004\end{array}$ & $\begin{array}{l}\text { Admin dapat menambah data } \\
\text { penyakit, pengobatan, gejala } \\
\text { dan relasi. }\end{array}$ \\
\hline $\begin{array}{c}\text { SRS-F- } \\
005\end{array}$ & $\begin{array}{l}\text { Admin dapat mengubah data } \\
\text { penyakit, pengobatan, gejala } \\
\text { dan relasi. }\end{array}$ \\
\hline $\begin{array}{c}\text { SRS-F- } \\
006\end{array}$ & $\begin{array}{l}\text { Admin dapat menghapus data } \\
\text { penyakit, pengobatan, gejala } \\
\text { dan relasi. }\end{array}$ \\
\hline
\end{tabular}




\begin{tabular}{|c|l|}
\hline SRS ID & \multicolumn{1}{|c|}{ Deskripsi Fungsional } \\
\hline $\begin{array}{c}\text { SRS-F- } \\
007\end{array}$ & $\begin{array}{l}\text { Admin dapat melakukan } \\
\text { pelatihan dengan algoritma } \\
\text { jaringan saraf tiruan } \\
\text { backpropagation. }\end{array}$ \\
\hline $\begin{array}{c}\text { SRS-F- } \\
008\end{array}$ & $\begin{array}{l}\text { Admin dapat menguji hasil } \\
\text { pelatihan. }\end{array}$ \\
\hline $\begin{array}{c}\text { SRS-F- } \\
009\end{array}$ & $\begin{array}{l}\text { Admin dapat melihat laporan } \\
\text { hasil diagnosa yang dilakukan } \\
\text { pasien. }\end{array}$ \\
\hline $\begin{array}{c}\text { SRS-F- } \\
010\end{array}$ & $\begin{array}{l}\text { Admin dapat menambahkan } \\
\text { akun baru. }\end{array}$ \\
\hline
\end{tabular}

Metode Jaringan Saraf Tiruan Backpropagation

Berdasarkan data penyakit yang didapat, arsitektur jaringan saraf tiruan backpropagation yang dibutuhkan adalah arsitektur yang terdiri dari satu layer masukan, satu layer tersembunyi dan satu layer keluaran. Layer masukan terdiri dari sebuah neuron bias dan empat buah neuron yang digunakan untuk mewakili masukan gejala berupa lokasi, warna, rasa dan tekstur. Layer tersembunyi terdiri dari sebuah neuron bias dan sejumlah neuron yang dapat ditentukan secara fleksibel. Semakin banyak neuron yang diberikan pada lapisan tersembunyi ini hasilnya akan semakin baik, namun dengan resiko kinerja pelatihan jaringan saraf tiruan backpropagation akan memakan waktu yang lebih lama. Layer keluaran terdiri dari sebuah neuron yang mewakili penyakit beserta pengobatannya.Fungsi aktivasi yang digunakan adalah fungsi aktivasi sigmoid biner.Arsitektur jaringan saraf tiruan backpropagation yang digunakan pada penelitian ini terdapat pada gambar 4.

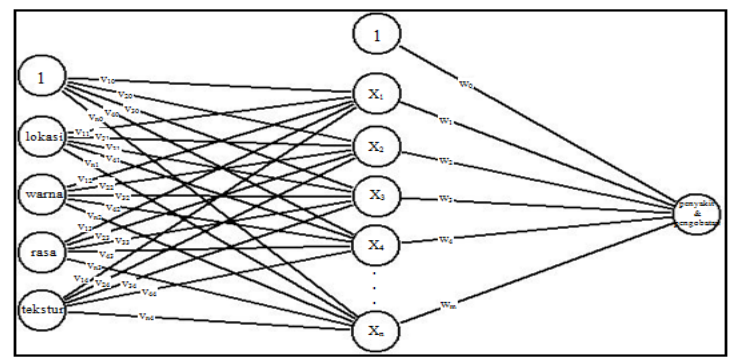

Gambar 4 Arsitektur Jaringan Saraf Tiruan

Backpropagation untuk Mendiagnosa Penyakit Kulit

\section{Pemodelan Fungsional}

DCD sistem informasi diagnosa penyakit kulit ini terdiri dua entitas yaitu pasien dan admin yang memiliki hak akses yang berbeda.

Pasien dapat melakukan diagnosa penyakit kulit dengan memasukkan data gejala yang ditampilkan oleh sistem informasi dengan memilih gejala yang diberikan dan kemudian pasien dapat melihat informasi hasil diagnosa penyakit.

Entitas kedua adalah admin yang memiliki hak akses lebih banyak daripada hak akses pasien.Admin dapat mengelola data penyakit, data gejala, data traintest, pelatihan, menguji hasil pelatihan, melihat laporan hasil diagnosa pasien dan dapat menambahkan data akun baru apabila terdapat admin baru.Data Context Diagram (DCD) / DFD level 0 sistem informasi diagnosa penyakit dengan algoritma jaringan saraf tiruan backpropagation ini ditunjukkan pada gambar 5 .

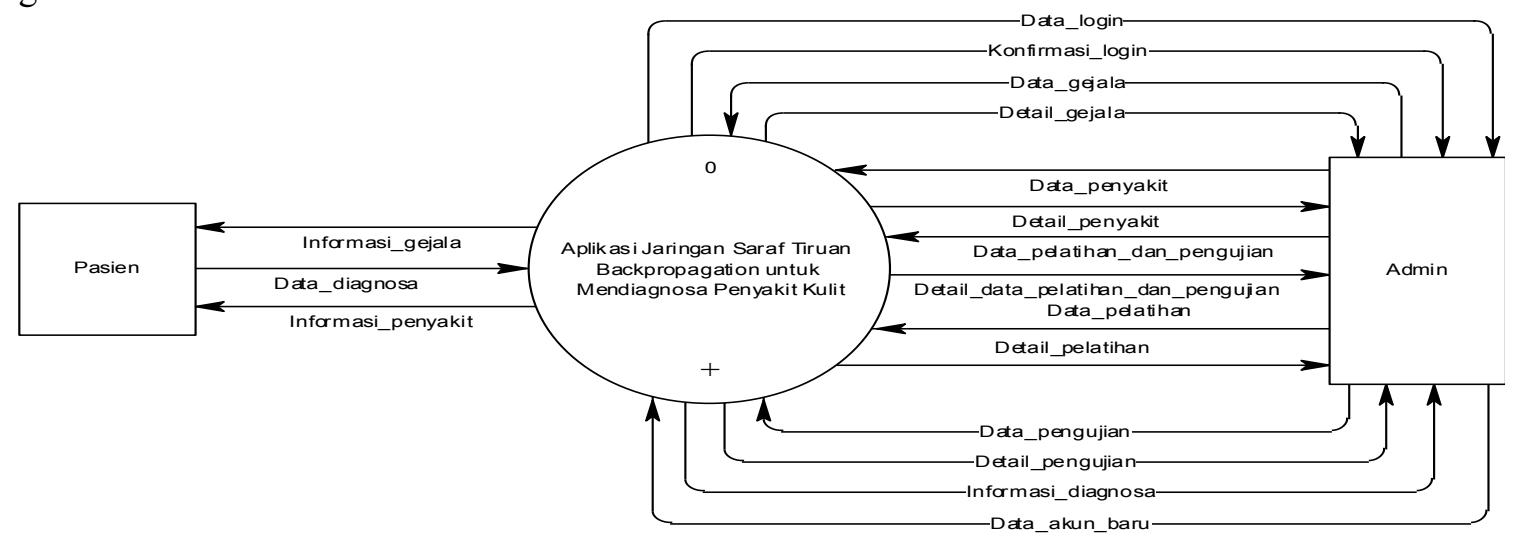

Gambar 5 DCD / DFD Level 0 Sistem Informasi Diagnosa Penyakit Kulit 


\section{IMPLEMENTASI DAN PENGUJIAN}

Sistem informasi jaringan saraf tiruan backpropagation untuk mendiagnosa penyakit memiliki antarmuka pada sisi pasien yang dapat digunakan untuk mendiagnosa penyakit kulit dengan mengisikan gejala berupa lokasi, warna, hal yang dirasakan dan tekstur dari penyakit kulit yang ditunjukkan pada gambar 6 .

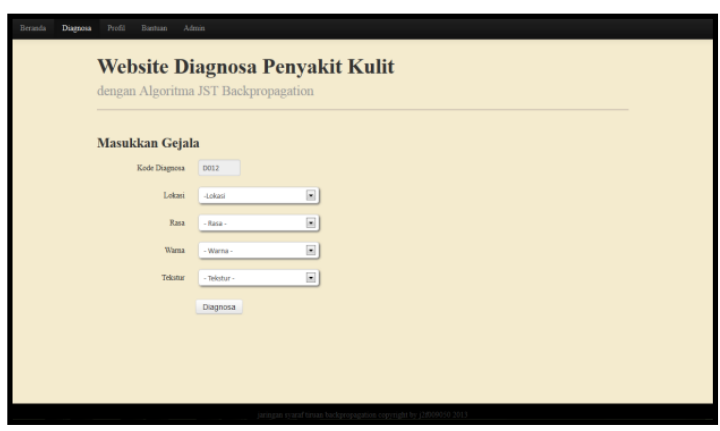

Gambar 6 Antarmuka Diagnosa

Sistem informasi ini akan memberikan hasil diagnosa sesuai dengan gejala yang dimasukkan seperti yang ditunjukkan pada gambar 7 jika hasil pengujian yang dilakukan oleh admin memiliki status benar. Namun jika pada pengujian data memiliki status salah maka sistem informasi ini akan memberikan hasil penyakit tidak terdiagnosa seperti yang ditunjukkan pada gambar 8. Hal tersebut bertujuan agar pasien tidak mendapatkan hasil diagnosa yang salah.

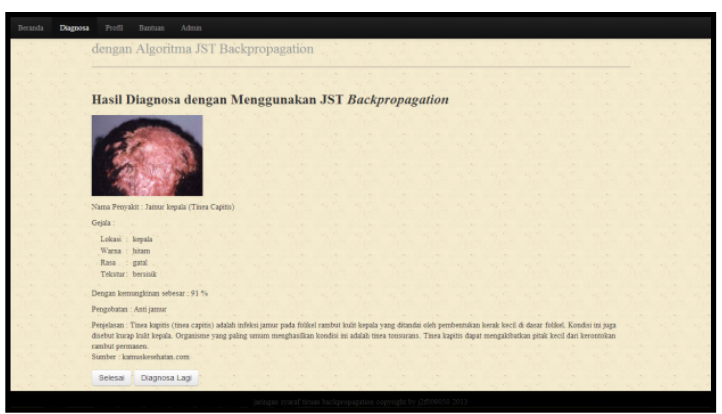

Gambar 7 Antarmuka Hasil Diagnosa

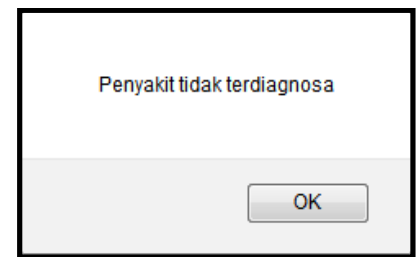

Gambar 8 Antarmuka Penyakit Tidak Terdiagnosa
Proses memasukkan data yang dapat digunakan untuk melakukan pelatihan dengan algoritma jaringan saraf tiruan backpropagation hanya dapat dilakukan oleh admin. Data yang dimasukkan berupa data gejala yang memiliki kategori lokasi, warna, hal yang dirasakan dan tekstur dari suatu penyakit kulit.Data pelatihan harus diisi terlebih dahulu sebelum melakukan pelatihan.Antarmuka data pelatihan dan data pengujian ditunjukkan pada gambar 9 .

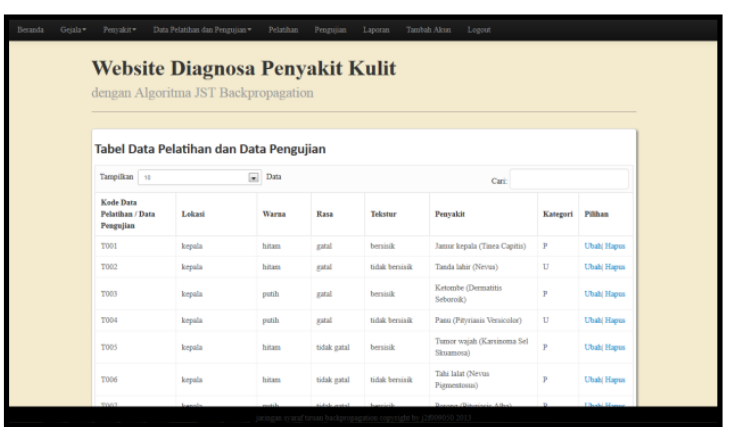

Gambar 9 Antarmuka Data Pelatihan dan Data Pengujian

Proses pelatihan dapat dilakukan jika data pelatihan sudah dimasukkan pada antamuka data pelatihan dan data pengujian. Admin dapat melakukan pelatihan data dengan memasukkan jumlah epoch, minimum error, laju pemahaman dan jumlah neuron pada lapisan tersembunyi yang diinginkan. Apabila terdapat data baru maka sebaiknya proses pelatihan dilakukan kembali. Antarmuka pelatihan dapat dilihat pada gambar 10.

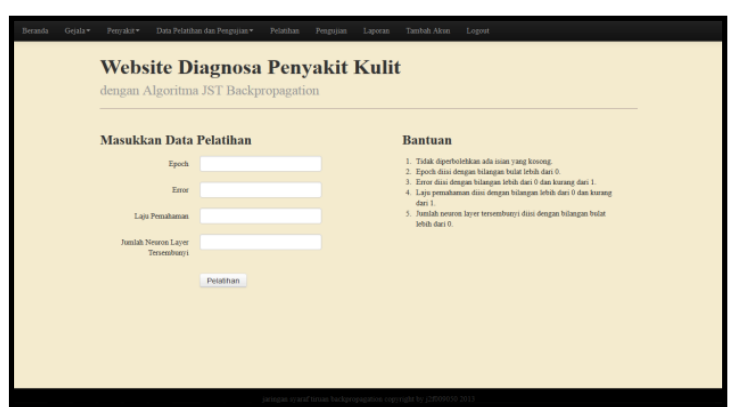

Gambar 10 Antarmuka Pelatihan

Proses pengujian baik untuk data pelatihan maupun data pengujian hanya dapat dilakukan oleh admin dan apabila proses pelatihan sudah dilakukan. Proses pengujian ini digunakan untuk melihat hasil pelatihan yang dilakukan apakah sudah memberikan hasil yang optimal dengan 
melihat status pada tabel pengujian. Hasil pengujian akan diperbarui jika admin melakukan pengujian ulang. Antarmuka pengujian dapat dilihat pada gambar 11 .

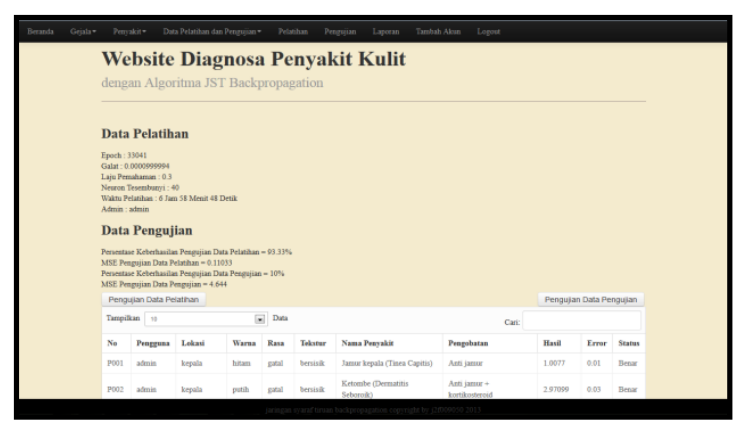

Gambar 11 Antarmuka Hasil Pengujian

Analisis Pelatihan dan Pengujian Jaringan Saraf Tiruan Backpropagation

Pelatihan dilakukan dengan berkali-kali melakukan uji coba berdasarkan laju pemahaman dan jumlah neuron pada layer tersembunyi dengan memasukkan data yang terdiri dari 30 data pelatihan dan hasil pelatihan dilakukan dengan melakukan pengujian terhadap data pelatihan yang sudah dilatih dan data pengujian yang belum dilakukan pelatihan sebelumnya.

Minimum error dan maksimum epoch yang dimasukkan pada setiap pelatihan yaitu sebesar 0.0001 dan 100000. Laju pemahaman yang dimasukkan semakin meningkat dari 0.3, 0.4, $0.5,0.6$ dan 0.7 serta dengan jumlah neuron tersembunyi yang semakin meningkat yaitu 10 , 20, 30, 40 dan 50.Tabel 7, tabel 8, tabel 9, tabel 10 dan tabel 11 menunjukkan hasil pelatihan dan pengujian berdasarkan laju pemahaman yang dimasukkan.

Tabel 7 Data Pengujian pada Laju Pemahaman (Learning Rate) Sebesar 0.3

\begin{tabular}{|l|c|c|c|c|c|}
\hline Percobaan ke- & $\mathbf{1}$ & $\mathbf{2}$ & $\mathbf{3}$ & $\mathbf{4}$ & $\mathbf{5}$ \\
\hline $\begin{array}{l}\text { Jumlah Neuron } \\
\text { Lapisan } \\
\text { Tersembunyi }\end{array}$ & 10 & 20 & 30 & 40 & 50 \\
\hline $\begin{array}{l}\text { Laju } \\
\text { Pemahaman }\end{array}$ & 0.3 & 0.3 & 0.3 & 0.3 & 0.3 \\
\hline \begin{tabular}{l} 
Epoch \\
\hline MSE Pelatihan
\end{tabular} & $\begin{array}{c}55976 \\
10^{-5}\end{array}$ & $\begin{array}{c}38144 \\
10^{-5}\end{array}$ & $\begin{array}{c}24331 \\
10^{-5}\end{array}$ & $\begin{array}{c}93041 \\
10^{-5}\end{array}$ & $\begin{array}{c}27938 \\
10^{-5}\end{array}$ \\
\hline $\begin{array}{l}\text { Persentase } \\
\text { Kebenaran } \\
\text { Data Pelatihan }\end{array}$ & $93.33 \%$ & $93.33 \%$ & $93.33 \%$ & $93.33 \%$ & $\begin{array}{c}96.67 \\
\%\end{array}$ \\
\hline \begin{tabular}{l} 
Persentase \\
\hline
\end{tabular} & $0 \%$ & $0 \%$ & $0 \%$ & $10 \%$ & $20 \%$ \\
\hline
\end{tabular}

\begin{tabular}{|l|c|c|c|c|c|}
\hline Percobaan ke- & $\mathbf{1}$ & $\mathbf{2}$ & $\mathbf{3}$ & $\mathbf{4}$ & $\mathbf{5}$ \\
\hline Kebenaran & & & & & \\
Data Pengujian & & & & & \\
\hline $\begin{array}{l}\text { Waktu } \\
\text { Pelatihan }\end{array}$ & $\begin{array}{c}1 \text { jam } \\
42 \\
\text { menit }\end{array}$ & $\begin{array}{c}5 \text { jam } \\
16 \\
\text { menit }\end{array}$ & $\begin{array}{c}3 \text { jam } \\
42 \\
\text { menit }\end{array}$ & $\begin{array}{c}6 \text { jam } \\
58 \\
\text { menit }\end{array}$ & $\begin{array}{c}7 \\
\text { menit }\end{array}$ \\
\hline
\end{tabular}

Tabel 8 Data Pengujian pada Laju Pemahaman (Learning Rate) Sebesar 0.4

\begin{tabular}{|l|c|c|c|c|c|}
\hline Percobaan ke- & $\mathbf{1}$ & $\mathbf{2}$ & $\mathbf{3}$ & $\mathbf{4}$ & $\mathbf{5}$ \\
\hline $\begin{array}{l}\text { Jumlah Neuron } \\
\text { Lapisan } \\
\text { Tersembunyi }\end{array}$ & 10 & 20 & 30 & 40 & 50 \\
\hline $\begin{array}{l}\text { Laju } \\
\text { Pemahaman }\end{array}$ & 0.4 & 0.4 & 0.4 & 0.4 & 0.4 \\
\hline Epoch & 28174 & 34073 & 30394 & 26767 & 32216 \\
\hline MSE Pelatihan & $\begin{array}{c}9.99 \times \\
10^{-5}\end{array}$ & $\begin{array}{c}9.99 \times \\
10^{-5}\end{array}$ & $\begin{array}{c}9.99 \times \\
10^{-5}\end{array}$ & $\begin{array}{c}9.99 \times \\
10^{-5}\end{array}$ & $\begin{array}{c}9.99 \times \\
10^{-5}\end{array}$ \\
\hline $\begin{array}{l}\text { Persentase } \\
\text { Kebenaran } \\
\text { Data Pelatihan }\end{array}$ & $96.67 \%$ & $100 \%$ & $100 \%$ & $\begin{array}{c}93.33 \\
\%\end{array}$ & $93.33 \%$ \\
\hline $\begin{array}{l}\text { Persentase } \\
\text { Kebenaran } \\
\text { Data Pengujian }\end{array}$ & $10 \%$ & $40 \%$ & $10 \%$ & $0 \%$ & $10 \%$ \\
\hline $\begin{array}{l}\text { Waktu } \\
\text { Pelatihan }\end{array}$ & $\begin{array}{c}32 \\
\text { menit }\end{array}$ & $\begin{array}{c}6 \text { jam } \\
10 \\
\text { menit }\end{array}$ & $\begin{array}{c}58 \\
\text { menit }\end{array}$ & $\begin{array}{c}30 \\
\text { menit }\end{array}$ & $\begin{array}{c}38 \\
\text { menit }\end{array}$ \\
\hline
\end{tabular}

Tabel 9 Data Pengujian pada Laju Pemahaman (Learning Rate) Sebesar 0.5

\begin{tabular}{|l|c|c|c|c|c|}
\hline $\begin{array}{l}\text { Percobaan ke- } \\
\begin{array}{l}\text { Jumlah Neuron } \\
\text { Lapisan } \\
\text { Tersembunyi }\end{array}\end{array}$ & 10 & 20 & 30 & 40 & 50 \\
\hline $\begin{array}{l}\text { Laju } \\
\text { Pemahaman }\end{array}$ & 0.5 & 0.5 & 0.5 & 0.5 & 0.5 \\
\hline Epoch & 40443 & 33600 & 15626 & 20268 & 12276 \\
\hline MSE Pelatihan & $\begin{array}{c}9.99 \times \\
10^{-5}\end{array}$ & $\begin{array}{c}9.99 \times \\
10^{-5}\end{array}$ & $\begin{array}{c}9.99 \times \\
10^{-5}\end{array}$ & $\begin{array}{c}9.99 \times \\
10^{-5}\end{array}$ & $\begin{array}{c}9.99 \times \\
10^{-5}\end{array}$ \\
\hline $\begin{array}{l}\text { Persentase } \\
\text { Kebenaran } \\
\text { Data Pelatihan }\end{array}$ & $93.33 \%$ & $100 \%$ & $100 \%$ & $96.67 \%$ & $93.33 \%$ \\
\hline $\begin{array}{l}\text { Persentase } \\
\text { Kebenaran } \\
\text { Data Pengujian }\end{array}$ & $10 \%$ & $0 \%$ & $10 \%$ & $20 \%$ & $0 \%$ \\
\hline $\begin{array}{l}\text { Waktu } \\
\text { Pelatihan }\end{array}$ & $\begin{array}{c}1 \text { jam } \\
\text { menit }\end{array}$ & $\begin{array}{c}38 \\
\text { menit }\end{array}$ & $\begin{array}{c}19 \\
\text { menit }\end{array}$ & $\begin{array}{c}25 \\
\text { menit }\end{array}$ & 15 menit \\
\hline
\end{tabular}

Tabel 10 Data Pengujian pada Laju Pemahaman (Learning Rate) Sebesar 0.6

\begin{tabular}{|l|c|c|c|c|c|}
\hline Percobaan ke- & $\mathbf{1}$ & $\mathbf{2}$ & $\mathbf{3}$ & $\mathbf{4}$ & $\mathbf{5}$ \\
\hline $\begin{array}{l}\text { Jumlah Neuron } \\
\text { Lapisan } \\
\text { Tersembunyi }\end{array}$ & 10 & 20 & 30 & 40 & 50 \\
\hline $\begin{array}{l}\text { Laju } \\
\text { Pemahaman }\end{array}$ & 0.6 & 0.6 & 0.6 & 0.6 & 0.6 \\
\hline Epoch & 19470 & 13540 & 19231 & 14417 & 13170 \\
\hline MSE Pelatihan & $\begin{array}{c}9.99 \mathrm{x} \\
10^{-5}\end{array}$ & $\begin{array}{c}9.99 \mathrm{x} \\
10^{-5}\end{array}$ & $\begin{array}{c}9.99 \mathrm{x} \\
10^{-5}\end{array}$ & $\begin{array}{c}9.99 \mathrm{x} \\
10^{-5}\end{array}$ & $\begin{array}{c}9.99 \mathrm{x} \\
10^{-5}\end{array}$ \\
\hline
\end{tabular}




\begin{tabular}{|l|c|c|c|c|c|}
\hline Percobaan ke- & $\mathbf{1}$ & $\mathbf{2}$ & $\mathbf{3}$ & $\mathbf{4}$ & $\mathbf{5}$ \\
\hline $\begin{array}{l}\text { Persentase } \\
\text { Kebenaran } \\
\text { Data Pelatihan }\end{array}$ & $93.33 \%$ & $96.67 \%$ & $96.67 \%$ & $\begin{array}{c}93.33 \\
\%\end{array}$ & $96.67 \%$ \\
\hline $\begin{array}{l}\text { Persentase } \\
\text { Kebenaran } \\
\text { Data Pengujian }\end{array}$ & $10 \%$ & $10 \%$ & $20 \%$ & $10 \%$ & $10 \%$ \\
\hline $\begin{array}{l}\text { Waktu } \\
\text { Pelatihan }\end{array}$ & $\begin{array}{c}5 \mathrm{jam} \\
11 \\
\text { menit }\end{array}$ & $\begin{array}{c}1 \mathrm{jam} \\
51 \\
\text { menit }\end{array}$ & $\begin{array}{c}5 \mathrm{jam} \\
51 \\
\text { menit }\end{array}$ & $\begin{array}{c}2 \text { jam } \\
4 \\
\text { menit }\end{array}$ & $\begin{array}{c}1 \text { jam } \\
29 \\
\text { menit }\end{array}$ \\
\hline
\end{tabular}

Tabel 11 Data Pengujian pada Laju Pemahaman (Learning Rate) Sebesar 0.7

\begin{tabular}{|c|c|c|c|c|c|}
\hline Percobaan ke- & 1 & 2 & 3 & 4 & 5 \\
\hline $\begin{array}{l}\text { Jumlah Neuron } \\
\text { Lapisan } \\
\text { Tersembunyi } \\
\end{array}$ & 10 & 20 & 30 & 40 & 50 \\
\hline \begin{tabular}{|l} 
Laju \\
Pemahaman \\
\end{tabular} & 0.7 & 0.7 & 0.7 & 0.7 & 0.7 \\
\hline Epoch & 13232 & 13733 & 13811 & 18090 & 17796 \\
\hline MSE Pelatihan & \begin{tabular}{|c|}
$9.99 \mathrm{x}$ \\
$10^{-5}$ \\
\end{tabular} & \begin{tabular}{|c|}
$9.99 \times$ \\
$10^{-5}$ \\
\end{tabular} & $\begin{array}{c}9.99 \mathrm{x} \\
10^{-5} \\
\end{array}$ & $\begin{array}{c}9.99 \times x \\
10^{-5} \\
\end{array}$ & \begin{tabular}{|c|}
$9.99 \mathrm{x}$ \\
$10^{-5}$ \\
\end{tabular} \\
\hline \begin{tabular}{|l} 
Persentase \\
Kebenaran \\
Data Pelatihan \\
\end{tabular} & $96.67 \%$ & $96.67 \%$ & $96.67 \%$ & $93.33 \%$ & $96.67 \%$ \\
\hline \begin{tabular}{|l} 
Persentase \\
Kebenaran \\
Data Pengujian \\
\end{tabular} & $0 \%$ & $0 \%$ & $0 \%$ & $0 \%$ & $10 \%$ \\
\hline $\begin{array}{l}\text { Waktu } \\
\text { Pelatihan }\end{array}$ & $\begin{array}{c}2 \text { jam } \\
4 \text { menit }\end{array}$ & $\begin{array}{c}2 \text { jam } \\
34 \\
\text { menit } \\
\end{array}$ & $\begin{array}{c}3 \text { jam } \\
6 \text { menit }\end{array}$ & \begin{tabular}{|c|}
3 jam \\
20 \\
menit \\
\end{tabular} & $\begin{array}{c}3 \text { jam } \\
4 \text { menit }\end{array}$ \\
\hline
\end{tabular}

Berdasarkan data pengujian pada tabel-tabel tersebut maka dapat disimpulkan bahwa pelatihan yang memberikan hasil yang paling optimal adalah pelatihan yang dilakukan dengan epoch 100000, error 0.0001, laju pemahaman 0.4 dan 20 neuron pada layer tersembunyi. Pelatihan tersebut menghasilkan persentase kebenaran $100 \%$ pada pengenalan data pelatihan dan $40 \%$ pada pengenalan data pengujian dengan waktu pelatihan selama 6 jam 10 menit, dengan kata lain dari 30 data yang dilatih dapat dikenali seluruhnya dan dari 10 data pengujian yang belum pernah dilakukan pelatihan hanya dapat dikenali 4 data saja.

\section{KESIMPULAN}

Berdasarkan hasil yang telah dicapai selama perancangan, implementasi dan pengujian perangkat lunak, maka dapat ditarik kesimpulan sebagai berikut :

1) Implementasi jaringan saraf tiruan backpropagation untuk mendiagnosa penyakit kulit berhasil diimplementasikan dengan menggunakan bahasa pemrograman PHP dan DBMS MySQL.

2) Jaringan saraf tiruan backpropagation dapat memberikan hasil yang paling optimal mengenali data yang diuji baik data yang sudah dilakukan pelatihan maupun untuk data yang belum dilakukan pelatihan pada jaringan yang pada saat pelatihan menggunakan 20 neuron pada layer tersembunyi, laju pemahaman 0.4 , minimum error 0.0001 dan maksimum epoch 100000 dengan waktu pelatihan selama 6 jam 10 menit. Hasil pengujian dari pelatihan tersebut menunjukkan persentase kebenaran pengujian data pelatihan sebesar $100 \%$ dan persentase kebenaran pengujian data yang belum pernah dilakukan pelatihan sebesar $40 \%$.

\section{UCAPAN TERIMA KASIH}

Penulis mengucapkan terima kasih kepada dr. Puguh Riyanto, Sp.KK selaku pakar yang telah memberikan bimbingan dan data mengenai penyakit kulit sehingga penelitian ini dapat diselesaikan dengan baik.

\section{DAFTAR PUSTAKA}

[1] Al-Bahra Bin Ladjamudin, 2006, "Rekayasa Perangkat Lunak", Graha Ilmu : Yogyakarta.

[2] Darmawan, D., 2010, "Pengenalan Wajah dengan Metode Backpropagation Menggunakan Kamera CCTV Inframerah", Program Sarjana Ekstensi, Universitas Indonesia, Depok.

[3] Hermawan, A., 2006, "Jaringan Saraf Tiruan, Teori dan Aplikasi”, Yogyakarta : Andi.

[4] Jumarwanto, Arif, Rudy H. dan Dhidik P., 2009, "Aplikasi Jaringan Saraf Tiruan Backpropagation untuk Memprediksi Penyakit THT di Rumah Sakit Mardi Rahayu Kudus", Semarang : Jurnal Teknik Elektro Vol.1, No.1.

[5] Kadir, A., 2008, "Tuntunan Praktis Belajar Database Menggunakan MySQL", Yogyakarta : Penerbit Andi. 
[6] Klokke, A.H., 1980, "Pedoman untuk Pengobatan Luar Penyakit Kulit”, Jakarta: Gramedia.

[7] Mardianto, I. dan Dian P., 2008, "Sistem Deteksi Penyakit Pengeroposan Tulang dengan Metode Jaringan Syaraf Tiruan Backpropagation dan Representasi Ciri dalam Ruang Eigen", Jakarta : CommIT Vol.2, No.1.

[8] Muttaqin, A. dan Kumala S., 2011, "Asuhan Keperawatan Gangguan Sistem Integumen", Jakarta : Salemba Medika.

[9] Pressman, R. S., 2001, "Software Engineering : A Practitioner's Approach", Edisi 5, McGraw - Hill Companies, Inc, New York.

[10] Puspitaningrum, D., 2006, "Pengantar Jaringan Saraf Tiruan", Yogyakarta : Andi.

[11] Shalahudin, M. dan Rosa A. S., 2007, "Modul Pembelajaran Pemrograman Berorientasi Objek dengan Bahasa Pemrograman $\mathrm{C}++$, PHP dan Java", Bandung : Modula.

[12] Siregar, R.S., 2005, "Atlas Berwarna Saripati Penyakit Kulit", Jakarta : Kedokteran EGC.

[13] Sommerville, I., 2001, "Software Engineering", Edisi 6, Addison Wesley.

[14] Suyanto, 2007, "Artificial Intelligenence", Bandung: Informatika.

[15] Yani, E., 2005, "Pengantar Jaringan Saraf Tiruan", MateriKuliah.Com.

[16] Yuwono, B., 2009, "Perancangan dan Implementasi Jaringan Saraf Tiruan untuk Mendiagnosis Jenis Penyakit Kandungan”, Yogyakarta : Jurnal Teknomatika Vol.2, No.1. 